\title{
Corporate Governance, Tax Avoidance, and Firm Value
}

\author{
Wawan Cahyo Nugroho ${ }^{1 *}$ and Dian Agustia ${ }^{2}$ \\ ${ }^{1,2}$ Airlangga University, Surabaya, Indonesia
}

\begin{abstract}
This study aims to examine: (1) the influence of institutional ownership, independent commissioners on tax avoidance on firm value (2) the influence of tax avoidance on firm value (3) the influence of institutional ownership, independent commissioner to firm value mediated by tax avoidance. The population of this study are manufacturing companies listed on the Indonesian Stock Exchange for the study from 2013-2016. This study purposive sampling and arrived at 92 firms, using path analysis technique. The results of this study indicates that (1) institutional ownership significantly influence tax avoidance (2) independent commissioners have no influence on tax avoidance; (3) institutional ownership does not influence the firm value; (4) independent commissioner and tax avoidance have significant effect to firm value; (5) tax avoidance does not mediate the institutional ownership relationship to firm value.
\end{abstract}

Keywords: Executive Incentives, Firm Value, Independent Commissioners, Institutional Ownership, Profitability, and Tax Avoidance

\section{INTRODUCTION}

Tax is a mandatory contribution that is compulsory and its levies are regulated by law addressed to every citizen either to an individual taxpayer or an indirect body of reciprocity but in its implementation to improve the welfare of the general public. To improve the general welfare of various people's lives, the government uses tax payments as a step for national development (Darmawan and Sukartha, 2014).

Many parties who contribute taxes to the state for example companies. In the calculation of corporate profits, tax costs are very important because the tax is a cost account that can reduce the amount of profits earned by the company for a year. The bigger the taxes that are deposited into the state treasury, the less profit the company generates in that year. Therefore many companies have various ways to reduce the amount of tax contribution to the country for example tax evasion. The company does not always welcome the government tax collection because the company's profits will be reduced by the large tax payments so companies will seek to minimize the tax contribution both legally and illegally, the government always wants the highest tax revenues possible cost of state development.

According to Fadhilah (2014) the way to reduce tax payments can be done in two ways: tax evasion and tax avoidance. Tax evasion provides several economic benefits to the company. To maximize corporate profits, management should seek to minimize the tax burden that is deposited as expected by shareholders. But shareholders also expect tax evasion by management to be done in the right amount because if too little will have an impact on the risk of fines and the value of the company will also decrease (Armstrong et al., 2015).

\footnotetext{
* Corresponding author. Email address: wawancahn@yahoo.com
} 
In companies that do tax avoidance there is a relationship between the investor as the principal with the manager as agent. According to Minnick and Noga (2010), investors always expect high profits and increase the firm value, so the shareholders want the tax paid to be minimized, while the manager as the tax evasion management also has a goal to the wealth owned by the company. Implementation of large tax evasion caused by the difference of interest between the taxpayer with the government and indicated by the ratio of tax revenue revenue by the government that has not reached the target so that it can be said the revenue of Indonesian state in the tax sector has not been optimal. Companies in Indonesia other than required to pay taxes are also required to implement corporate governance, especially for listed companies whose shares are listed on the Indonesia Stock Exchange (IDX).

According to Annisa and Kurniasih (2012) corporate governance is a system that explains the direction of corporate performance that links the interests of shareholders with corporate managers. These different interests are commonly called agency conflicts and can be minimized with the implementation of corporate governance. The existence of agency conflict because there is a difference of interest to be achieved by shareholders that are not in line with the interests of corporate management. Profit earned by the company will be used as a basis for payment of income tax. Large profits also have an impact on large tax payments as well. The presence of a large burden will affect the company in tax avoidance but with a small risk so that companies need to implement corporate governance.

Institutional ownership is the proportion of ownership of a share owned by an institution such as an investment company, an insurance company and a banking or other institution as measured by the percentage of the number of shares held (Fadhilah, 2014). In this study, institutional ownership will be examined in the company's policy of tax avoidance by the management of the company, because the ownership of institutional ownership have a large proportion of companies listed on the IDX and know how effective and efficient in monitoring the performance of corporate managers, especially in decision making Field of taxation.

Independent Commissioner in this case act as a bridge in the supervision of the decision of the manager of the company because the independent commissioner more independent and impartial between the interests to be achieved by investors who own majority ownership or minority ownership (Raharja, 2014). Based on the idea that the higher the proportion of independent commissioners within the company, it is hoped that the empowerment of the board of commissioners can perform the task of supervising and giving advice to the directors effectively and giving added value to the company.

The company in its business activities has a goal to be able to increase the value of the company in each period, which can be seen from the stock market price. According to Fama and French in Agustia (2012), the optimization of corporate value improvement can be achieved through how well the implementation of financial management functions, This is related to decisions taken by management in every company activity. Tax evasion is a management decision that can affect tofirm value.

Previous research on tax evasion has been done by Armstrong et al. (2015) indicating that corporate governance and executive incentives have an effect on tax evasion while Fadhilah's (2014) study shows that institutional ownership and independent board of commissioners have no effect on tax avoidance. Research on tax avoidance on corporate value is also done by Desai and Dharmapala (2009) which the result shows tax avoidance is not significant to firm value. This research will combine some previous studies to examine the direct and indirect influence of corporate 
governance on corporate value through tax avoidance. This study aims to: (1) examine the effect of institutional ownership, independent commissioner to tax avoidance and firm value (2) to examine the effect of tax avoidance on firm value (3) to examine the effect of institutional ownership, independent commissioner to firm tax avoidance value as intervening variable.

\section{LITERATURE STUDY AND HYPOTHESIS DEVELOPMENT Agency Teory}

Jensen and Meckling in Maharani and Suardana (2014) explain there is a cooperation contract between shareholders consisting of several people (principal) with managers (agents) to manage the resources of shareholders including delegating obligations to managers in making policies for decision making . Relationship theory of the agency with this research is the difference of interests between managers as agents with shareholders are always principal. Managers as the company's management take tax avoidance measures by increasing the costs incurred to make the profit before taxes will be reduced, while the shareholders want the profits generated high company with the aim to obtain dividends distributed to shareholders as well as possible.

Tax

The definition of tax mentioned in the General Provisions and Procedures of Taxation contained in the Law of the Republic of Indonesia Number 28 Year 2007 Article 1 point 1 explains that tax is the contribution of the taxpayer to the state owed by an individual or a coercive body under the Act, By not getting the rewards directly and used for the purposes of the state for the size of the people's prosperity. Mardiasmo (2009: 8) states that the tax collection system used in Indonesia can be divided into 3 (three) systems: (1) Official Assessment System, (2) Self Assessment System, (3) With Holding System

\section{Tax Avoidance}

According to Budiman (2012) tax avoidance actions conducted by managers for the benefit of shareholders I s not a deliberate action so that tax avoidance action will give a problem to the manager because it will be contrary to moral problems because acting in accordance with the interests of shareholders. The moral problem in question is that managers also expect the return of tax avoidance in the form of additional resources or other benefits. Thus, shareholders will reward managers, among others, will provide compensation that will encourage managers to always be more optimal in improving the performance of the company so that will increase the value of the company one of them by tax avoidance (Desai and Dharmapala, 2006).

\section{Firm Value}

Shareholders expect the funds invested in providing prosperity that will increase the value of the company. The stock market price may reflect the value of the firm (Nugroho, 2014). Rising stock prices will provide welfare for shareholders. One of the ratios that can measure the company's value is the tobin's $\mathrm{Q}$. The tobin's $\mathrm{Q}$ ratio is able to accurately reflect the information, since this tobin's $Q$ can provide accurate information in the company's activities such as the cross-sectional in the investment decision process taken. If the value of tobin's Q increases, the value of the company increases and gives a better picture of the company's survival. According to Raharja (2014) if the shareholders in issuing sacrifices in the ability of the company because it is measured by the increasing price of shares that is reflected by the market value compared with the value of his book. 


\section{Corporate Governance}

According to Haruman (2008) corporate governance is a system of corporate governance to improve the achievement of a regular company between the various parties who formed a contractual relationship in a company. Management as an agent is given the responsibility of running the company to achieve the purpose given by the shareholder as principal so that management is obliged to always report its activities to shareholders. Corporate governance has principles of openness, accountability, responsibility, independence and fairness. Based on the agency perspective, the existence of corporate governance can provide oversight and the most important thing in managing corporate taxes.

\section{Institutional ownership}

Institutional ownership is the amount of wealth in the form of shares owned by the institution and blockholders (Fadhilah, 2014). This individual shareholder is always active in comparison with individual shareholders who own shares under $5 \%$. To oversee the behavior of managers in decision-making requires the role of institutional ownership to be more cautious in their decision-making (Shleifer and Vishny, 1986). With the existence of institutional ownership have the following role in supervision, among others: (1) Have reliability information so that information obtained can be more reliable, (2) Have motivation in every activity for supervision that happened to be more controlled.

\section{Independent Commissioner}

Independent commissioners mean people who are neutral ie there is no relationship between the majority shareholder and the board of directors and board of commissioners (Raharja, 2014). The existence of independent commissioners acts as an independent and objective party in providing balance between various parties, especially the majority shareholder or minority shareholder with stakeholders such as the manager, creditor, debtor, or other parties related in the interests of the company. 


\section{Analisys Model}

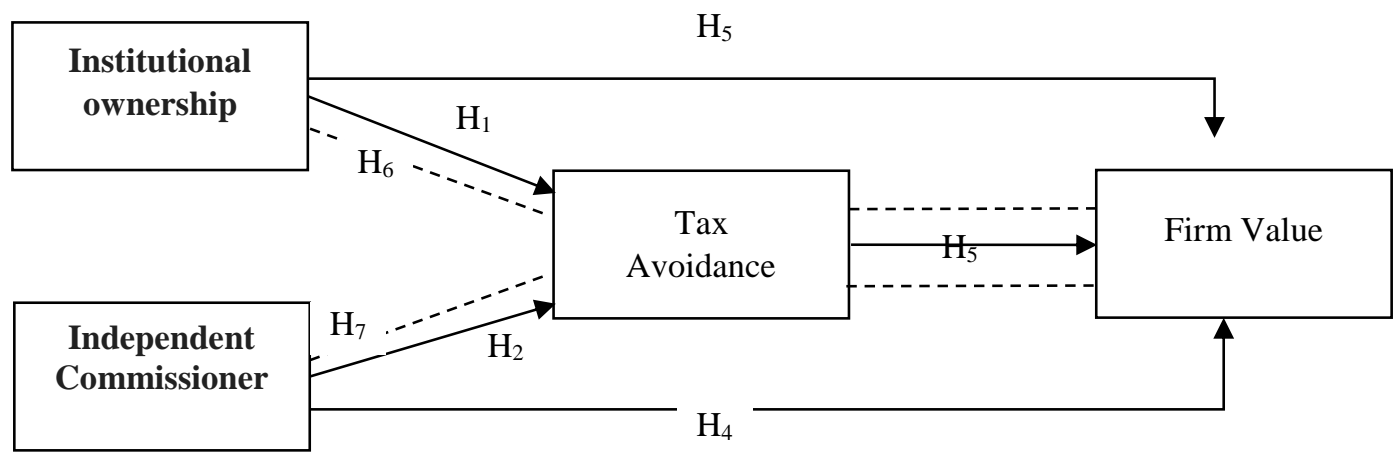

Figure 1 Analisys Model

\section{Hypotheses Development}

\section{The Influenceof Insitutional Ownership on Tax Avoidance}

Institutional ownership is the proportion of ownership of a share owned by an institution such as an investment company, an insurance company and a banking or other institution as measured by the percentage of the number of shares held (Fadhilah, 2014). Institutional ownership serves to oversee management policies, since institutional ownership plays a role in monitoring the various policies that managers take in making decisions so that decisions are taken to provide effectiveness to the company. This study supports the study of Annisa and Kurniasih (2012) which states that institutional leadership has a positive effect on company value. Institutional ownership has the ability to control the management through an effective monitoring process so that it will affect the management action to tax avoidance, the higher the percentage of institutional ownership, the level of supervision to the manager will be more effective so that the agency conflict will be reduced so that tax avoidance will also be less .

\section{$\mathrm{H}_{1}$ : Institutional ownership negatively affects tax avoidance}

\section{The Influence of Independent Commissioner on Tax Avoidance}

Companies with independent commissioners will be able to improve management performance control so that the greater the independent commissioner owned by the company, the supervision for the management becomes more optimal. The more optimal supervision of management makes managers will be more careful in every decision making and more open in running all activities undertaken in the company so that will reduce the occurrence of tax avoidance (Ardyansah and Zulaikha, 2014). The results of this study are consistent with the research of Armstrong et al. (2015) indicating that the proportion of independent commissioners negatively affects tax avoidance so that if the number of independent commissioners increases then tax avoidance that occurs in the company can also be minimized.

$\mathrm{H}_{2}$ : Independent Commissioner negatively affects tax avoidance 


\section{The Influence of Institutional Ownership on Firm Value}

The presence of more dominant institutional ownership will further encourage institutional shareholders to be more optimal in supervising management activities. This can prevent the manager's opportunistic behavior. According to Arif in Bernandhi and Muid (2014) the existence of higher institutional ownership will increase supervision to the management so that it will minimize the abuse of authority that may cause the company value will decrease. Suhartanti (2015) shows that institutional ownership has a significant negative effect on firm value because if the institutional ownership level increases, the company value decreases, and vice versa. This suggests that the proportion of high institutional ownership in a company creates more pressure and desire from institutional investors.

\section{$\mathrm{H}_{3}$ : Institutional ownership negatively affects firm value}

\section{The Influence of Independent Commissioner on Firm Value}

Independent commissioners are in control in directing the company to run operations in accordance with predetermined standards so that corporate objectives can be achieved well. Achievement of corporate goals is inseparable from the role of independent commissioners who oversees managers to work with the company-oriented advancement, thus the value of the company will increase. According to Raharja (2014) the existence of independent commissioners as an intermediary between the interests of majority investors with minority investors, this is because independent commissioners will act more objectively and independently in every decision taken by the company's management. The results of his research conclude that the board of independent commissioners has a significant positive effect on the value of the company.

\section{$\mathrm{H}_{4}$ : Independent commissioners have a positive effect on firm value}

\section{The Influenceof Tax Avoidance on Firm Value}

Tax avoidance is a management measure to reduce corporate tax payable by certain steps in accordance with the tax laws. Desai research and Dharmapala (2006) explains that companies that implement corporate governance with optimal will have a significant impact on the management policy in tax avoidance against the value of the company. Research Jonathan and Tandean (2016) states that tax avoidance has a significant positive effect on the value of the company. In signal theory explained that the company by providing clear financial statements will be able to increase investor interest so that the value of the company will increase. Thus with the existence of these financial statements, the investor can analyze how the company's actions in terms of tax avoidance and increase investor confidence in the company's management.

\section{$\mathrm{H}_{5}$ : Tax avoidance has a positive effect on firm value}

\section{The Influence of Institutional Ownership on Firm Value through Tax Avoidance}

According to Khurana and Moser in Annisa and Kurniasih (2012) which states that the size of institutional ownership will affect the aggressive tax policy by the company. Tax evasion is often done by the company can be done because solely indeed take advantage of existing regulations and for business purposes. Research conducted by Lim in Hanum and Zulaikha (2013) also explains that the increased tax avoidance effect in the interest of shareholders (lower tax burden) may be affected by shareholder activity 
through greater involvement of institutional investors, where shareholders Greater ownership of the institutional shareholders will impose restrictions on management aimed at minimizing the tax amount and increasing its own wealth. However, viewed from different views, management actions to conduct tax avoidance activities based on monitoring from the institution will be able to increase the value of the company.

\section{$\mathrm{H}_{6}$ : Tax avoidance mediates institutional ownership of Firm value}

\section{The Influence of Independent Commissioner on Corporate Value through Tax Avoidance}

Independent Commissioners together with other boards carry out supervisory duties and determine a favorable policy strategy for the company, but do not violate any laws included in the determination of tax-related strategies. With an independent commissioner, any formulation of corporate strategy undertaken by the board of commissioners and the management of the company and its stakeholders will provide effective and efficient result guarantee including policies related to tax avoidance measures (Hanum and Zulaikha, 2013). The role of independent commissioners in monitoring the activities of tax planning on corporate value has been investigated by Desai and Dharmapala (2009) stating that independent commissioners have a negative effect on tax planning relationships with firm value.

\section{$\mathrm{H}_{7}$ : Tax avoidance mediates an independent commissioner of Firm value}

\section{RESEARCH METHODOLOGY}

\section{Population and Sample Research}

In this study the population used is all manufacturing companies listed on the Indonesia Stock Exchange (IDX) in 2013-2016. Sampling technique of the company using purposive sampling method. The company's sample in this research is 92 manufacturing companies.

\section{Independent Variables}

\section{Institutional ownership}

Institutional ownership is the proportion of ownership of a share owned by an institution such as an investment company, an insurance company and a banking or other institution as measured by the percentage of the number of shares held (Fadhilah, 2014). According to Shleifer and Vishny (1986) argue that with the voting rights held within the company, institutional owners can encourage management to stay concerned about the company's future and avoid behaving for its own sake. Institutional ownership can be calculated using the ratio of:

\footnotetext{
KepIns $=\underline{\text { Institutional ownership }}$

\section{Independent Commissioner}

\section{$\sum$ Share}

According to Raharja (2014) states that an independent commissioner is assigned as an unaffected party in many respects either with investors or with directors or board of commissioners and does not serve as director of a company. The existence of independent commissioners aims as an intermediary and objective to the interests of corporate management with the interests of stakeholders. Independent Commissioners can be calculated using the ratio of:
} 


$$
\text { KomInd }=\frac{\sum \text { Independent Commissioner }}{\sum \text { Commissioner }}
$$

\section{Dependent Variables Firm Value}

The value of the company reflects the views of shareholders or other potential investors on the company's ability to manage the resources reflected in the share price (Soebiantoro, 2007). Measurement of company value is proportional to Tobin's Q. Tobin's Q has advantages over other firm's value ratios because this ratio in addition to complex in its calculations can also show the current financial market estimates of the return value of each fund invested compared to the other company's value calculations. This ratio is used by previous research conducted by Tommy (2010) whose Tobin's Q ratio is measured by:

$$
\mathrm{NP}=\frac{\mathrm{MVA}+\mathrm{D}}{\mathrm{TA}}
$$

\section{Intervening Variables}

\section{Tax Avoidance}

Tax avoidance allows the policy taken by management to marshal the impact on taxation to reduce the tax payable that is deposited to the State by exploiting the weaknesses of the tax law and not violating the tax laws. Tax avoidance in this study is proxied by CASH ETR (cash effective tax rate), which is the calculation of the amount of taxes paid compared to the company's pre-tax profit (Dyreng et al., 2010).

CASH ETR can be calculated by

$$
\text { CETR }=\frac{\text { Payment of Taxes }}{\text { Earning Before Tax }}
$$

\section{Hypothesis testing}

In accordance with the frame of thought it can create two structural equations namely:

$$
\begin{array}{cc}
\text { CETR } & =\alpha+\beta_{1} \text { KepIns }+\beta_{2} \text { KomInd }+\varepsilon \ldots \ldots \ldots \ldots \ldots \\
\mathrm{NP} & =\alpha+\beta_{1} \text { KepIns }+\beta_{2} \text { KomInd }+\beta_{3} \text { CETR }+\varepsilon
\end{array}
$$

Information:

$\begin{array}{ll}\text { CETR } & =\text { Cash Effective Tax Rate } \\ \text { NP } & =\text { Firm Value } \\ \text { KepIns } & =\text { Institutional ownership } \\ \text { KomInd } & =\text { Independent commissioner } \\ \alpha & =\text { Constanta } \\ \beta_{1}-\beta_{3} & =\text { Regression Coefficient } \\ \mathrm{e} & =\text { error terms }\end{array}$

\section{RESEARCH RESULT AND DISCUSSION} Descriptive Statistics Analysis

Descriptive statistics provide information about the description of the variables used in the study. Descriptive statistics in this study can be seen in table 1 below: 
Corporate Governance, Tax Avoidance, and Firm Value

Table 1 Descriptive Analysis

\begin{tabular}{cccccc}
\hline & N & Minimum & Maximum & Mean & Std. Deviation \\
\hline NP & 368 & 0,2618 & 18,6404 & 1,8876 & 2,5488 \\
CETR & 368 & 0,0075 & 4,3768 & 0,4475 & 0,4818 \\
KepIns & 368 & 0,0180 & 0,9933 & 0,7146 & 0,1906 \\
KomInd & 368 & 0,2000 & 0,8000 & 0,3983 & 0,1019 \\
\hline
\end{tabular}

From Table 1 above can be seen the number of observations under study as many as 368 observations, based on the last 4 periods of annual financial statements (20132016). The value of the firm has the lowest of 0.2618 and the highest is 18,6404 . The average value of the company owned by the whole company is 1.8876 with the standard deviation 2,5488. Management actions in tax avoidance have the lowest value of 0.0075 and the highest value of 4.3768 . Average tax avoidance by the company as a whole is 0.4475 with a standard deviation of 0.4818 . The lowest institutional ownership of research sample is 0,0180 and the highest is 0,9933 . The average institutional ownership of the institution as a whole is 0.7146 with a standard deviation of 0.1906 . Independent commissioner of the lowest research sample is 0.2000 and the highest is 0.8000 . Independent commissioners of the study sample as a whole have an average of 0.3983 with a standard deviation of 0.1019 .

\section{Hypothesis testing}

Test Hypothesis 1 and 2

The result of calculation through SPSS 20 (Statistical Program for Social Science) application on hypothesis 1 and 2 test is as follows:

Table 2 Multiple Linear Regression Analysis Hypotheses 1 and 2

\begin{tabular}{lccc}
\hline \multicolumn{1}{c}{ Variable } & $\begin{array}{c}\text { Regression } \\
\text { Coefficient }\end{array}$ & $\mathbf{t}$ & Sig. \\
\hline Constant & 0,220 & & \\
Institutional ownership (KepIns) & 0,355 & 2,803 & 0,005 \\
Independent commissioner (KomInd) & 0,312 & 1,288 & 0,198 \\
\hline
\end{tabular}

Test Hypothesis 3, 4, and 5

Table 3 Multiple Linear Regression Analysis Hypotheses 3,4, and 5

\begin{tabular}{lccc}
\hline Variable & $\begin{array}{l}\text { Regression } \\
\text { Coefficient }\end{array}$ & $\mathrm{t}$ & Sig. \\
\hline Constant & $-2,080$ & & \\
Institutional ownership (KepIns) & 0,019 & 0,048 & 0,962 \\
Independent commissioner (KomInd) & 4,655 & 6,084 & 0,000 \\
Tax Avoidance (CETR) & 0,740 & 4,475 & 0,000 \\
\hline
\end{tabular}

\section{Results and Discussion}

\section{The Influence of Institutional Ownership on Tax Avoidance}

Based on the results of regression analysis showed that institutional ownership positively influence tax avoidance with regression coefficient 0,355 and significance value equal to 0,005 . With a significance value of 0.005 this shows that $\mathrm{H}_{1}$ accepted so that in this study institutional ownership positively effect the behavior of tax avoidance conducted by the management company. Institutional ownership serves to oversee management policies, since institutional ownership plays a role in monitoring the various 
policies that managers take in making decisions to make effective decisions on the company (Fadhilah, 2014).

The result of this research institutional ownership structure can influence how company management make decision about taxation policy especially tax evasion so that institutional ownership have positive effect to tax avoidance. This is because companies that have high institutional ownership will be more aggressive in minimizing tax reporting. So the higher the composition of institutional ownership, the corporate governance implementation mechanism will be more effective so that corporate tax avoidance system will also be implemented in accordance with the planning and will have an impact on increasing tax avoidance practices by company management. The growing practice of tax avoidance will affect the profits generated by the company each year so that institutional ownership is oriented to maximize their welfare, especially in the profits to be gained, the amount of profits earned by the company annually will affect the amount of dividends distributed by institutional shareholders. This study supports the study of Annisa and Kurniasih (2012) which states that institutional leadership has a positive effect on company value.

\section{The Influence of Independent Commissioner on Tax Avoidance}

Based on the result of regression analysis indicate that independent commissioner has no effect to tax avoidance with regression coefficient 0,312 and significance value equal to 0,198 . The significance value of 0.198 indicates that $\mathrm{H}_{2}$ is rejected so in this study independent commissioners have no effect on tax avoidance behavior conducted by company management. Independent commissioners should be able to improve management performance control so that the greater the independent commissioner owned by the company, the supervision for the management becomes more optimal so that managers will be more careful in every decision making and more open in carrying out all activities undertaken in the company so that will reduce the occurrence Tax avoidance (Ardyansah and Zulaikha, 2014).

The results of this study are independent commissioners have no effect on management actions in tax avoidance. The large number of independent commissioners does not affect tax avoidance because independent board members can not show their independence so that the supervisory function on management is not running optimally and will have an impact on the lack of supervision on the management action in tax avoidance. This is due to the difficulty of coordination among independent commissioners and this impedes the oversight process which should be the responsibility of the independent board of commissioners. The number of boards of commissioners in this manufacturing company is not a major determinant of the effectiveness of oversight of corporate management. The small number of independent board of commissioners does not affect tax avoidance activities. The explanation of this result is that an independent commissioner in a manufacturing company is merely a formality to comply with the regulations of the Indonesia Stock Exchange in accordance with the rules of the financial services authority NO.33/POJK.04/2014 which contains the board of commissioners of at least 2 (two) members of the board commissioner. In the event that the board of commissioners consists of more than 2 (two) members of the board of commissioners, the number of independent commissioners shall be at least $30 \%$ (thirty percent) of the total members of the board of commissioners, so that the independent commissioner is not to perform a good monitoring function Using its independence to oversee the company's management policies. This study supports Fadhilah (2014) research indicating that independent commissioners have no effect on tax avoidance because not all independent commissioners can show their independence so that the 
supervisory function does not go well and impact on the lack of oversight of management in tax avoidance.

\section{The Influence of Institutional Ownership on Firm Value}

Based on the results of regression analysis shows that institutional ownership does not affect the company value with regression coefficient 0.019 and significance value of 0.962. The significance value of 0.962 indicates that $\mathrm{H}_{3}$ is rejected so that in this study institutional ownership has no effect on firm value. The presence of more dominant institutional ownership will further encourage institutional shareholders to be more optimal in supervising management activities. This can prevent the manager's opportunistic behavior. The results of this study have no effect on institutional ownership of the value of the company, this is due to the large or small institutional ownership of the company has not been able to control and oversee the actions of opportunistic managers within the company. The opportunistic actions of managers in too large firms can not be controlled by institutional investors efficiently as institutional investors will focus more on corporate profits than opportunistic managers. This is supported by average pre-tax profit data from 2013-2016 (as shown in table 4 below):

Table 4 Average Earning Before Tax

\begin{tabular}{cc}
\hline Average Earning Before Tax & Mean \\
\hline 2013 & 1.128 .688 .000 .000 \\
2014 & 1.115 .297 .000 .000 \\
2015 & 1.045 .295 .000 .000 \\
2016 & 1.254 .123 .000 .000 \\
\hline
\end{tabular}

Based on table 4, in 2016, the average profit before tax of manufacturing companies increased significantly by $20.31 \%$ compared to 2015 , because in 2014 and 2015 experienced a decrease in profit before tax so that institutional shareholders will strive for how to increase profit Company and in 2016 has increased. This indicates that institutional ownership will see how the company maximizes the company's profit so that the amount of profit each year will have an impact on the amount of dividend to be shared by the shareholders. This research supports Sinarmayarani research (2016) which shows that the existence of independent commissioners does not affect the value of the company. This is due to the fact that the large or small institutional ownership of the company has not been able to control and oversee the opportunistic actions of managers within the company.

\section{The Influence of Independent Commissioner on Firm Value}

Based on the result of regression analysis indicate that independent commissioner has significant influence to company value with regression coefficient 4,655 and significance value equal to 0.000 . This significance value of 0.000 indicates that $\mathrm{H}_{4}$ is accepted so that in this study independent commissioners have a significant positive effect on firm value. Independent commissioners are in control in directing the company to run operations in accordance with predetermined standards so that corporate objectives can be achieved well. Achieving corporate goals is inseparable from the role of independent commissioners who oversee managers to work with the company's ongoing orientation, thereby increasing company value (Raharja, 2014).

The results in this study in accordance with the theory that the independent commissioner has a significant positive effect on the value of the company. This indicates that the more independent members of the commissioner then the process of 
supervision of management in the operational activities and preparation of financial statements made will be more objective and effective so as to improve the performance of the company. With the increase in corporate performance due to the effective supervision of independent commissioners then of course investors are willing to pay more expensive and high value shares in manufacturing companies. From the results of this study can be said that the board of independent commissioners more objective in conducting supervision of the board of directors and managers so that the performance of the board of directors is very effective and efficient which ultimately affects the increasing value of the company. The results of this study support the results of Raharja (2014) which concludes that the board of independent commissioners positively affect the value of the company. The existence of an independent commissioner as an intermediary between the interests of the majority investor and the minority investor, this is because the independent commissioner will act more objectively and independently in every decision taken by company management.

The Influence of Tax Avoidance on Firm Value

Based on the results of regression analysis showed that tax avoidance has significant effect to firm value with regression coefficient 0,740 and significance value equal to 0.000 . This significance value of 0.000 indicates that $\mathrm{H}_{5}$ is accepted so that in this study tax avoidance has a positive effect on firm value. Tax avoidance actions by the company can increase the value of the company, because the profits that can be by the company will be greater (Jonathan and Tandean, 2016).

The results of this study indicate that tax avoidance has a significant positive effect on firm value, it is explained that high tax avoidance indicates good corporate value so investors will respond positively to the signal and the value of the company is increasing. This is as revealed in research by Chasbiandani and Martani (2012) that the lower the cash effective tax rate (CETR) of a company, the higher the value of the company. This is also in line with signal theory and agency theory. In signal theory explained that the company by providing clear financial statements will be able to increase investor interest so that the value of the company will increase. Thus with the existence of these financial statements, the investor can analyze how the company's actions in terms of tax avoidance and increase investor confidence in the company's management. And in the agency theory explained that there is a difference of interest between management and shareholders because shareholders have low control, so if in this case if the company management tax avoidance to reduce the tax burden and mengefisiensikan profit company, the investor expectations to get more profit Big will be realized. The results of research are in line with the results of research by Jonathan and Tandean (2016) which states that tax avoidance has a positive effect on firm value. Desai and Dharmapala (2006) research also explains that companies that implement corporate governance optimally will have a significant impact on management policies in tax avoidance on corporate value.

The Influence of Institutional Ownership on Firm Value through Tax Avoidance

The results of the test show that tax avoidance does not mediate the institutional ownership relationship to firm value. This is because the value of $t$ arithmetic smaller than $\mathrm{t}$ table with a significance level of 0.05 is $0.2698<1.966$. Thus the hypothesis (H10) is rejected, meaning tax avoidance indirectly can not mediate the relationship between profitability to firm value.

Tax avoidance can not mediate the relationship between profitability to corporate value because tax evasion is often done by the company can be done because it simply takes advantage of existing rules and for business purposes. Companies that own larger 
shares are owned by other companies or government institutions, then the performance of the company's management to be able to earn profit in accordance with the desired will tend to be supervised by institutional investors. This may encourage management to affect the amount of tax payable by the company. Based on the research result, the average tax avoidance rate conducted by the sample company is still above the average effective tax rate applicable from the year $2013-2016$ of $44.75 \%$. The results of this study indicate that tax avoidance is not a major factor that can affect institutional investor confidence in corporate value. The main factor that can attract institutional investor confidence is the profit of the company which always increases every year. This is in accordance with table 4 which indicates that the average profit before corporate taxes in 2016 has increased significantly from 2015 so that even if the company's management does not do tax avoidance will not affect institutional investors' trust in assessing the value of the company proxied with Rise in stock prices. If the company's profits increase annually it will increase the share price of the manufacturing company and automatically the value of the company will also increase.

The Influence of Independent Commissioner on Firm Value through Tax Avoidance

Partially independent commissioners have no effect on tax avoidance and corporate value. Therefore, path analysis through Sobel test to test tax avoidance as a mediation variable is not done because independent commissioner is not a factor affecting tax avoidance so it can be stated that in the research model formed tax avoidance is not mediation between the influence of independent commissioner to company value.

\section{CONCLUSION}

\section{Conclusion}

The results of this study indicate that (1) institutional ownership significantly influence tax avoidance (2) independent commissioners have no effect on tax avoidance; (3) institutional ownership does not affect the firm value; (4) independent commissioner and tax avoidance have significant effect to firm value; (5) tax avoidance does not mediate the institutional ownership relationship to firm value.

\section{Limitations}

Based on the limitations of the research, the suggestions that can be given are (1) Further research is more recommended to expand the population and sample research into all industry sectors listed on the BEI in order to get a picture of how much tax avoidance rates made by companies in Indonesia in various industry sectors , (2) Further research is suggested to add corporate governance variables as a whole and other variables that can describe tax aggressiveness so that it can describe tax avoidance actions by companies in Indonesia.

\section{References}

Agustia, D. (2012). Pengaruh Profitabilitas dan Likuiditas terhadap Nilai Perusahaan dengan Struktur Modal sebagai Variabel Intervening. Jurnal Akuntansi KePerilakuan Indonesia, 2 (1).

Annisa, N. A., \& Kurniasih, L. (2012). Pengaruh corporate governance terhadap Tax avoidance. Jurnal Akuntansi \& Auditing, 8(2), 95-189. 
Ardyansah, D., \& Zulaikha. (2014). Pengaruh Size, Leverage, Profitability, Capital Intersity Ratio dan Komisaris Independen terhadap Effective Tax Rate (ETR). Diponegoro Journal Of Accounting, 3(2), 1-9.

Armstrong, C. S., Blouin, J. L., Jagolinzer, A. D., \& Larcker, D. F. (2015). Corporate governance, incentives, and tax avoidance. Journal of Accounting and Economics, 60(1), 1-17.

Bernandhi, R., \& Muid, A. (2014). Pengaruh Kepemilikan Manajerial, Kepemilikan Institutional, Kebijakan Dividen, Leverage, dan Ukuran Perusahaan terhadap Nilai Perusahaan. Diponegoro Journal Of Accounting, 3(1).

Budiman, J. (2012). Pengaruh Karakter Eksekutif terhadap Penghindaran Pajak (Tax avoidance). [Theses]. Yogyakarta: Universitas Gadjah Mada.

Chasbiandani, T., \& Martani, D. (2012). Pengaruh Tax Avoidance Jangka Panjang Terhadap Nilai Perusahaan. [Theses]. Depok: Universitas Indonesia.

Darmawan, I., \& Sukartha, I. (2014). Pengaruh Penerapan Corporate Governance, Leverage, Roa, dan Ukuran Perusahaan pada Penghindaran Pajak. E-Jurnal Akuntansi, 9(1), 143-161.

Desai, M. A., \& Dharmapala, D. (2006). Corporate tax avoidance and high-powered incentives. Journal of Financial Economics, 79(1), 145-179.

. (2009). Corporate tax avoidance and firm value. The Review of Economics and Statistics, 91(3), 537-546.

Dewan Komisioner Otoritas Jasa Keuangan. (2014). Peraturan Otoritas Jasa Keuangan Nomor 33 /POJK.04/2014 tentang Direksi dan Dewan Komisaris Emiten atau Perusahaan Publik.

Dyreng, S. D., Hanlon, M., \& Maydew, E. L. (2010). The effects of executives on corporate tax avoidance. The Accounting Review, 85(4), 1163-1189.

Fadhilah, R. (2014). Pengaruh Good Corporate Governance terhadap Tax avoidance (Studi Empiris Pada Perusahaan Manufaktur yang Terdaftar di BEI 2009-2011). Jurnal Akuntansi, 2(1).

Hanum, H.R \& Zulaikha. (2013). Pengaruh Karakteristik Corporate Governance Terhadap Effective Tax Rate (Studi Empiris pada BUMN yang Terdaftar di BEI 2009-2011).Diponegoro Journal Accounting.2: 1-10.

Haruman, T. (2008). Struktur Kepemilikan, Keputusan Keuangan dan Nilai Perusahaan UU Pasar Modal No.8 Tahun 1995. Jurnal Keuangan \& Perbankan Perbanas, Vol. $10(2), 1-6$.

Jonathan, \& Tandean, V. A. (2016). Pengaruh Tax avoidance terhadap Nilai Perusahaan dengan Profitabilitas sebagai Variabel Pemoderasi. Jurnal Unisbank Semarang.

Maharani, I., \& Suardana, K. A. (2014). Pengaruh Corporate Governance, Profitabilitas, dan Karakteristik Eksekutif pada Tax avoidance Perusahaan Manufaktur. E-Jurnal Akuntansi, 9(2), 525-539. 
Mardiasmo. (2009). Perpajakan. Yogyakarta: Penerbit Andi.

Minnick, K., \& Noga, T. (2010). Do corporate governance characteristics influence tax management? Journal of corporate finance, 16(5), 703-718.

Nugroho, W. C. (2014). Dampak Kebijakan Dividen pada Pengaruh Kinerja Keuangan terhadap Nilai Perusahaan Pertambangan Di Bursa Efek Indonesia. Jurnal Ilmu dan Riset Akuntansi, 3(12).

Raharja, R. S. P. (2014). Analisis Pengaruh Corporate Governance terhadap Nilai Perusahaan. Diponegoro Journal Of Accounting, 3(3), 1-13.

Shleifer, A., \& Vishny, R. W. (1986). Large shareholders and corporate control. Journal of political economy, 94(3, Part 1), 461-488.

Sinarmayarani, A. (2016). Pengaruh Kepemilikan Institutional dan Profitabilitas terhadap Nilai Perusahaan Melalui Kebijakan Dividen. Jurnal Ilmu dan Riset Manajemen, 5(5).

Soebiantoro, U. (2007). Pengaruh struktur kepemilikan saham, leverage, faktor intern dan faktor ekstern terhadap nilai perusahaan. Jurnal Manajemen dan Kewirausahaan, 9(1), 41-48.

Suhartanti, T. (2015). Pengaruh Corporate Governance terhadap Nilai Perusahaan dengan Kinerja Keuangan Sebagai Variabel Moderating. Jurnal Ilmu dan Riset Akuntansi, 4(8).

Tommy, P. (2010). Konsentrasi Kepemilikan Saham, Risiko Perusahaan, Likuiditas Saham, Arus Kas, dan Nilai Perusahaan. Jurnal Keuangan dan Perbankan, 14, 641-651.

Undang-Undang Republik Indonesia Nomor 28 Tahun 2007 Tentang Ketentuan Umum Dan Tata Cara Perpajakan. 